\title{
NEUROMELANIN-CONTAINING, CATECHOLAMINERGIC NEURONS IN THE HUMAN BRAIN: ONTOGENETIC ASPECTS, DEVELOPMENT AND AGING
}

\author{
Dimitar E. Itzev ${ }^{1}$, Wladimir A. Ovtscharoff ${ }^{2}$, Enrico Marani ${ }^{3}$, and Kamen G. Usunoff ${ }^{1-3}$ \\ ${ }^{1}$ Institute of Physiology, Bulgarian Academy of Sciences, Sofia, Bulgaria, ${ }^{2}$ Department of Anatomy \\ and Histology, Preclinical University Center, Medical University, Sofia, Bulgaria, ${ }^{3}$ Department \\ of Neurosurgery, Leiden University Medical Center, Leiden, The Netherlands
}

The present review compiles data on the development and aging of neuromelanin (NM)-containing neurons in the central nervous system. Neuromelanin is brownish-to-black pigment that accumulates in the catecholaminergic (noradrenergic and dopaminergic) neurons and is a reliable natural marker that delineates the A1-A14 catecholaminergic groups of Dahlstrom and Fuxe in the human brain. The pigmentation of noradrenergic locus ceruleus neurons starts earlier than that of dopaminergic substantia nigra, but also a considerable individual variability is present. The pigmentation is well advanced in adolescence. The data at what age the maximal pigmentation is reached are controversial, as are the data on the cell loss in the NM-containing neuronal populations by normal aging. Thus, the participation of NM in the pathogenesis of Parkinson's disease remains enigmatic.

Biomed Rev 2002; 13: 39-47.

\section{INTRODUCTION}

The brownish-to-black pigment neuromelanin (NM) accumulates in catecholaminergic (CAergic) neurons in the central nervous system of humans and apes, and to a lesser extent - in other primates, ungulates and carnivores (reviewed in 1). Although the majority but not all CAergic neurons contain $\mathrm{NM}(2,3)$, this pigment is a reliable natural marker of CAergic neurons, and several atlases are present $(1,4,5)$ that demonstrate the A1-A14 CAergic neuronal groups of Dahlstrom and Fuxe (6) in the human brain.

The NM-containing neurons are involved in severe diseases, including motor disorders, mainly the idiopathic Parkinson's disease and in Parkinson-plus syndromes (7-12, and refs. therein) and Alzheimer's disease (13-17, and refs. therein).

Marsden (18) reasonably asks: "Neuromelanin is closely linked to Parkinson's disease, but is it the cause of the illness?"
The issue is controversial and is discussed in numerous reports (19-22, and refs. therein). The data on the normal aging of NMcontaining neurons are especially important, when considering the development of neurodegenerative diseases, characterized primarily by the cell loss of CAergic neurons. The present review compiles the data on the development and aging of NM-containing CAergic neuronal cells in the brain of man and other mammals.

\section{NEUROMELANIN IN DEVELOPMENT}

According to Friede (23), Stilling (24) was the first to note that pigmentation in the brain stem is absent in very young children. Pilcz (25) observed pigmentation of the human locus ceruleus (LC) by 11-12 months and of the substantia nigra (SN) by the third year of life. Calligaris (26) found no pigmentation in LC of children up to the ninth month. Like

Received 22 August 2002 and accepted 30 November 2002.

Correspondence and reprint requests to Dr Dimitar E. Itzev, Institute of Physiology, Bulgarian Academy of Sciences,

Acad. Georgi Bonchev Str. Block 23, BG-1113 Sofia, Bulgaria. Tel.: 359(2)979 3215, Fax: 359(2)71 9109 ,

E-mail: itzev@bio.bas.bg 
Pilcz, he states that the pigment formation starts at about the $11^{\text {th }}$ and $12^{\text {th }}$ months and is well developed by the second year. Pigmentation of SN develops approximately a year later than that in LC, and adult-like pigmentation is evident by about 1018 years. However, Cooper (27) had noticed NM-containing $\mathrm{SN}$ neurons in a fetus at the $5^{\text {th }}$ month of gestation (she used silver techniques known to be more efficient than the routine stainings). Mettler (28) states that the pigmentation of SN neurons begins in the third year, is well advanced by the $6^{\text {th }}$ but not completed until $16^{\text {th }}$ or $18^{\text {th }}$ year of life. Olszewski and Baxter (29) report the presence of melanized LC neurons in five year old child but that are not seen in SN. Foley and Baxter $(30,31)$ have examined 100 brains from fetuses, infants and children under the age of 5 years. They encounter NM in a fetal $\left(5^{\text {th }}\right.$ month) LC, but deny its presence in SN before 18 months after birth. These significant discrepancies are probably due to natural individual variations, to the limited numbers of the examined brains, and to the different criteria in recognizing reliable melanin granules. In addition, Nieto et al (32), Fenichel and Bazelon (33), Mann et al (34), and Barden (35) stressed the limited reliability of the classical staining techniques (for the same reason large discrepancies appear in the description of changes in aging as well as in the comparative anatomy). Using the diamine silver technique of Lillie (36), Fenichel and Bazelon (33) examined 44 brains: from the $34^{\text {th }}$ gestational week to 16 years of age. Their results show that great individual variability indeed exists, since they reported that $\mathrm{SN}$ is "routinely pigmented" at the age of 5 years, but the youngest brain to contain NM in SN was 5 months old. These authors present the only report so far of NM existence in the dorsal vagal nucleus (DVN) - in the most immature brain examined by them (34 weeks of gestation). The method used appears to be of great importance. Cowen (37) used the diamine silver technique (36) and Schmorl's ferric ferricyanide method (38) to demonstrate the melanoneurons of human cerebellum already at the $26^{\text {th }}$ week of gestation. On the other hand, with routine staining methods, the brown granules in the NM-containing neurons of the pars cerebellaris loci cerulei were shown by Cowen only after 2,5 years after birth.

It was repeatedly shown that when NM first appears, the individual granules are smallest in size $(35,39-42)$, least in number $(31,35,41,43,44)$, and the pigment in the youngest individuals occupies the smallest intraperikaryal volume $(34,43$ 46). Fenichel and Bazelon (33) describe a rapid increase of melanin content in SN, LC and DVN that reaches its maximum at 16 years of age. Thus, SN and LC can already be identified grossly at preadolescence. Although these authors investigate also adult brains (47), they have apparently concentrated their investigation mainly on brainstems of infants and children as to conclude that the maximal pigmentation is reached at puberty. Other researchers declare a longer development. According to Moses et al (42), the maximum is reached between 20 and 30 years of age. In a painstaking series of cytophotometric investigations, Mann and his colleagues established that the percent of strongly pigmented cells in SN and LC progressively increases from 18 months to 60 years $(34,44,48,49)$. Similarly, Graham (45), who calculates both the perikaryal volume and its NM content in 10, 40 and 80 year old brains, shows not only a sharp increase between the first and the $4^{\text {th }}$ decade, but also that the volume of the pigment in the $8^{\text {th }}$ decade is twice more abundant than in the fourth decade. On the other hand, Gellerstedt (50) was the first to describe a decline in the NM content of the SN and LC in aging of people without detectable neurologic disease, while Adler (39) found the same amount of pigment in 18 and 68 year old brains. According to Moses et al (42), the amount and distribution of NM in SN and LC in 20-30 year old brains is comparable with 58, 70 and 82 year-old brains of people without neurological disease. The precise quantitative estimations of Mann and Yates $(43,44)$ and Mann et al $(34,51)$ demonstrate that a gradual decline takes place from 60 to 90 years in all NM-containing nuclei, and especially - in SN. These authors propose that the decline in the quantity of the pigment is due to loss of the heavily loaded with NM perikarya, and that the loss of NM is greatest in the ventromedial and dorsal $\mathrm{SN}$, in contrast to the ventrolateral focus of degeneration in Parkinson's disease $(7,8,43,44,52,53)$. The number of NM-containing nigral neurons (52,54-56), but not tyrosine hydroxylase (TH)-immunopositive neurons (57) decreases at a rate of $\sim 5 \%$ per decade. In 36 control cases ranged in age from 21 to 91 years, Fearnley and Lees (52) reported a decline of 4,7\% per decade, and the total decrease reached $33 \%$. There was a significant sparing of the ventrolateral and ventrointermediate groups in SN pars compacta - $15 \%$ cell loss. On the other hand, exactly these groups are most severely affected by idiopathic Parkinson's disease - the heaviest cell loss involves the dorsal tier of pars compacta $(48 \%)$, followed by pars lateralis $(46 \%)$. Faraldi et al (58) estimated the amount of NM in hematoxylin-eosinstained sections of SN pars compacta in 69 cases, 14 to 100 years old. The mean area of cellular NM showed a curvilinear increase from $103 \mu \mathrm{m}^{2}$ at age 14 , to $600 \mu \mathrm{m}^{2}$ at age 67 before dropping down to $328 \mu \mathrm{m}^{2}$ at age 100 . By contrast, the fraction of NM area relative to perikaryal area showed a linear increase with age. The latter and an increase of NM pigmented perikarya from $83 \%$ at age of 14 to almost $100 \%$ at age of 65 or older, accounted for the increase of NM mean area. By contrast, a decrease in the mean area of neuronal perikarya and a decrease in the number of profiles of neuronal cell bodies explained the decrease of NM mean area beyond age of 67. Faraldi et al (58) support the hypothesis that an overload of NM is neurotoxic and emphasize the importance of using age-matched controls in histopathologic studies of the SN. Mann et al (49), and Mann and Yates (48) established that the increased amount of NM correlates with a reduction of the cytoplasmic and nucleolar RNA. Mann et al (49) suggest that the death of neurons maximally accumulating NM is due to a reduction in protein synthesizing ability directly associated with the physical displacement and dysruption of cytoplasmic RNA. In 
this regard, Barden (40) points out the impaired function of the Golgi-apparatus in NM-containing neurons in old monkeys. Unlike the interpretations of Mann's group $(34,43,44,49)$, Graham $(45,59)$ proposed that the atrophy and cell death of the melanized neurons is a consequence of the intraneuronal toxicity of the cytotoxic quinone precursors of NM.

\section{CATECHOLAMINERGIC NEURONAL LOSS IN AGING}

Neuronal loss in SN with aging is also verified by biochemical studies. Riederer and Wuketich (60) establish a 13\% reduction of caudate nucleus dopamine content per decade. Carlsson et al (61) report a non-linear decline of striatal dopamine with little loss until the age of 60 , followed by a dramatic fall in the following decades. Scherman et al (62) assessed striatal dopamine levels by measuring the binding of alpha-dihydrotetrabenazine, a ligand of the vesicular monoamine transporter and found a linear decline of under $10 \%$ per decade. It is generally assumed that the neuronal loss in normal aging is not sufficient to cause Parkinson's disease (52 and refs. therein). In Parkinson's disease, there is a presymptomatic phase and clinical signs do not appear until 50\% of nigral neurons and $80 \%$ of striatal dopamine are lost (see 63 ).

There is a considerable body of literature, reporting a decrease in LC neuron number with advancing age, similarly to SN (14,46,64-74, and refs. therein). Most studies have used NM as a cell marker of noradrenergic neurons, and some studies have additionally used immunohistochemical staining with antibodies against $\mathrm{TH}(46,73,75)$, or against dopamine- $\beta$-hydroxylase $(68,73)$. However, the data of the total number of LC neurons at different age are contradictory in both cell number and age-dependency, and often the comparative evaluation of the data is difficult (see 74). The reported mean cell numbers range from approximately 6,000 $19,000(68,69,72,76)$ to about $27,000-32,000$ per side $(77,78)$. In brains from four young individuals (1-28 years of age), Manaye et al (46) found an average of 21,000 LC and nucleus subceruleus neurons in one hemisphere, counting both TH and NM-containing neurons. Lohr and Jeste (72), and Manaye et al (46) reported linear age-related changes, while other authors $(14,64,66,70,79)$ found non-linear changes. In LC and nucleus subceruleus, neuronal loss of up to $40 \%$ in the $7^{\text {th }}$ decade and up to $48 \%$ by the $9^{\text {th }}$ decade was described (64). The authors found a mean number of approximately 14,000 $\pm 3,500$ neurons ( 24 individuals between 14 and 87 years). The mean for the group under 60 years was $16,840 \pm 2,320$, whereas the group above 60 had a mean of 13,378 $\pm 2,141$ neurons. ChanPalay and Asan (73) distinguish rostral, middle and caudal portions of LC, that contain four neuronal types in different proportions. They point out that cell loss in the old adult brain shows a topographical arrangement with a distinct rostrocaudal gradient. Cell loss is highest in the rostral LC part, displaying a reduction of $54.3 \%-62.9 \%$, it is $21.6 \%-32.4 \%$ in the middle part, and $1.8 \%-15.4 \%$ in the caudal part, which is greatly spared. Manaye et al (46) investigated 17 cases (1-104 years of age) and reported that from the first to $10^{\text {th }}$ decade of life there is over $50 \%$ loss of LC neurons. On the other hand, Ohm et al (74) find no correlation between the age of the individuals and the cell number. Their study involves 20 cases (49-98 years of age), all of which - carefully examined for absence of neurological or psychiatric disorders. These researchers report a mean number of NM-containing LC neurons per side $15,731 \pm 3,408$, with a quite broad range: $11,737-25,319$. At a variance to the studies cited above, Mouton et al (80), state that there is no change in pigmented cell number or size in the LC of nondemented older persons as compared with that of young individuals. An important point that at least partially explains these controversies is proposed by Manaye et al (46). According to them, the magnitude of LC neuronal loss that occurs with aging depends upon whether the cell marker is NM or TH-immunostaining. Manaye et al (46) insist that although $\mathrm{NM}$ is a useful marker of CAergic neurons in the human brain, $\mathrm{NM}$ is not a reliable marker for LC neurons in brains under 50 years of age. They demonstrate that below age of 25 there are much fewer NM-containing neurons than TH-containing neurons in LC. Manaye et al recall the data of Graham (45), who examined the area of the LC neurons occupied by NM in the first, $4^{\text {th }}$ and $8^{\text {th }}$ decade - there was a doubling of cellular area occupied by NM from first to the $4^{\text {th }}$ decade, and again from the $4^{\text {th }}$ to the $8^{\text {th }}$ decade of life. Thus, Manaye et al (46) proposed that in studies in which brains less than 50 years of age had been used $(64,69,70,72,76)$, counting of pigmented cells results in an underestimation of their number.

The data focused on whether aging results in a random loss of LC neurons throughout the nucleus or whether different rostrocaudal portions of the nucleus age at different rates, are also controversial. Marcyniuk et al (76) find a random cell loss, whilst Chan-Palay and Asan (81) establish a non-random cell loss in LC. Manaye et al (46) report a statistically significant interaction between age group and magnitude of rostrocaudal cell loss. They describe that in the rostral portion of LC there is a substantial age-related cell loss, whilst in the caudal portions of the nucleus little or no cell loss occurs. Recently, Kubis et al (82) provided unexpected data. They examined the human TH-immunostained neuronal population in SN, ventral tegmental area (VTA), peri- and retrorubral area, central gray substances and LC in 21 control subjects who died at ages 44110 years. They found no statistically significant cell loss of $\mathrm{TH}$ positive neurons in the older subjects, either in the $\mathrm{SN}$ or in the remaining CAergic neuronal groups that degenerate to a lesser degree in Parkinson's disease. Kubis et al (82) concluded that from middle age to 110 years, aging in control adults is not (or is scarcely) accompanied by CA-containing cell loss in the mesencephalon, hence Parkinson's disease is probably not caused by an acceleration of a degenerative process during aging.

Although more scant, and only rarely with precise quantitative measurements, there are data for an increased 
pigmentation in aged animals: chimpanzee and orangutan (83), gorilla (84), dog (85-88), cat $(85,89,90)$, rhesus monkey $(40,41,91)$, and horse (92). Herrero et al (93) estimated the distribution and number of NM-positive neurons in Macaca fascicularis, aged 0-13 years, by means of calculating unstained NM-containing neurons, or stained with Masson silver impregnation, and by $\mathrm{TH}$-immunocytochemistry. At birth, no unstained NM-positive neurons were detected, but Masson-stained cells were observed in LC. At 8 and 13 years, unstained NM was present in Masson-positive neurons. Herrero et al (93) state that a differential increase in NM content with age in the neurons of mesencephalic catecholamine group is present. Irwin et al (94) examined young, intermediateaged and old squirrel monkeys. Contrary to the obvious functional and neurochemical age-related changes (70\% loss of dopamine in $\mathrm{SN}$, and $30 \%$ in the putamen), the number of $\mathrm{TH}$-immunoreactive cells did not significantly differ among the three age groups. Pakkenberg et al (91) examined the number of pigmented and nonpigmented neurons in the SN of young and old Macaca mulatta monkeys. They found that the total number of pigmented neurons was about eight times higher in old animals compared with young ones $(166,000$ versus 21,400), while the total number of non-pigmented SN neurons was less than half in old animals compared with young ones (139,000 versus 285,000). Siddiqi and Peters (95) point out that with age, all of the neurons in rhesus monkey SN accumulate lipofuscin, especially the small multipolar GABAergic neurons. These authors also report that although both neurons and neuroglial cells are affected with age, no entities that could be construed to be dying neurons might be encountered.

The CAergic neurons in rodents do not contain $\mathrm{MN}$ $(90,96,97)$. There is a considerable body of data based on cell loss and TH-immunostaining but the reports are somewhat contradictory. In the ASH/TO mouse, a significant loss of LC cells has been observed by Sturrock and Rao (98). They found a $47 \%$ decrease in Nissl-stained LC neurons in 31-monthold mice, compared to 6- and 15-month-old mice. Shores et al (99) also found a LC cell loss in Brown-Norway rats but reported that the TH mRNA expression increases, which may potentially increase norepinephrine synthesis in the remaining neurons. We investigated the noradrenergic neuronal systems in young (3-month-old) and very old (26-28-month-old) Wistar rats by means of dopamine- $\beta$-hydroxylase immunostaining (Figs. 1, 2). The cell loss in LC and nucleus subceruleus is obvious (Fig. 1a-d). In young rats (Fig. 1a, c) the cell density in LC is so high that it is difficult to discriminate the individual immunopositive neuronal perikarya. On the other hand, the decreased cell density in aged rats improves the visualization of individual neurons (Fig. 1b, d). In young rats, the immunostaining is present also in distal dendrites (Fig. 1f). In old rats, only proximal dendritic stumps are visualized (Fig. 1e). Alongside the atrophy of the cell processes, the amount of dopamine- $\beta$-hydroxylase is probably also decreased. The differences between young and aged rats in noradrenergic axon numbers are drastic (Fig. 2a, b). The number of immunolabeled axons in the medial forebrain bundle on the territory of the lateral hypothalamus is greatly reduced in the aged rats. Also, the axonal immunostaining is considerably more pale in old animals, so that only individual axonal varicosities are comparable to those in young rats. Tatton et al (100) and Greenwood et al (101) investigated the SN and LC in C57B1 mice aged 8 to 104 weeks, and found that the neuronal loss was due to neuronal death rather than loss of THimmunoreactivity. The cytoplasmic TH was increased by $63 \%$ in 104-week-old mice in comparisson to 8-week-old animals. McNeill et al $(102,103)$ investigated the $\mathrm{SN}$ in young and aged C57B1/6N Nia mice. They found a progressive accumulation of cytoplasmic lipofuscin granules and a markedly reduced dopamine content per cell as determined by histofluorescence. Further, McNeill and Koek (104) investigated six age groups (3 - 30 months aged) of C57BL/6N mice, and reported a small decline $(11 \%)$ in the total number of dopamine neurons of the SN with age, a decrease not reaching a statistical significance. Voogt et al (105) did not observe detectable changes in TH mRNA levels in the rat SN with age. Emerich et al (106) also reported a lack of reduction in number, area and length of THimmunoreactive neurons within the A8, A9 or A10 region of aged (24-25 month old) rats. Schuligoi et al (107) suggested that the reduction in TH mRNA in the VTA and SN pars compacta in 33-month-old Sprague-Dawley rats is not due to a loss of TH mRNA expressing cells but due to a reduction in the hybridization signal per expressing cell. Himi et al (108) investigated the expression of mRNAs encoding the dopamine transporter and TH in SN of young and aged Fischer 344 rats. They found that dopamine transporter mRNA decreases by 18 months, whilst TH mRNA reduction does not occur until 24 months. Finally, De La Cruz et al (109) report a significant decrease of TH activity in $\mathrm{SN}$ in rats between 12 and 24 months of age.

Figure 1. Low power view of the dorsal pontine tegmentum in young (a) and old rat (b). Fig. 1c is a detail from Fig. 1a. The strong immunostaining and the great neuronal density impedes the visualization of individual neurons in LC (upper part of the figure, but individual neurons are clearly demonstrated in nucleus subceruleus dorsalis (central and lower part of the figure). Fig. $1 \boldsymbol{d}$ is a detail from Fig. $\mathbf{1 b}$. Both the cell loss and decreased immunostaining are obvious in the old rat. Fig. le is a detail from Fig. 1d. Neuronal group in the nucleus subceruleus. Only the proximal parts of the dendritic trunci are visualized. Compare with Fig. $1 \boldsymbol{f}$ - strongly immunostained neuron in nucleus subceruleus ventralis of a young rat. The cell nucleus is unstained but the reaction product extends also to distal portions of the dendrites. a,b $x 40 ; \boldsymbol{c}, \boldsymbol{d} \times 100 ; \boldsymbol{e}, \boldsymbol{f} \times 400$. 


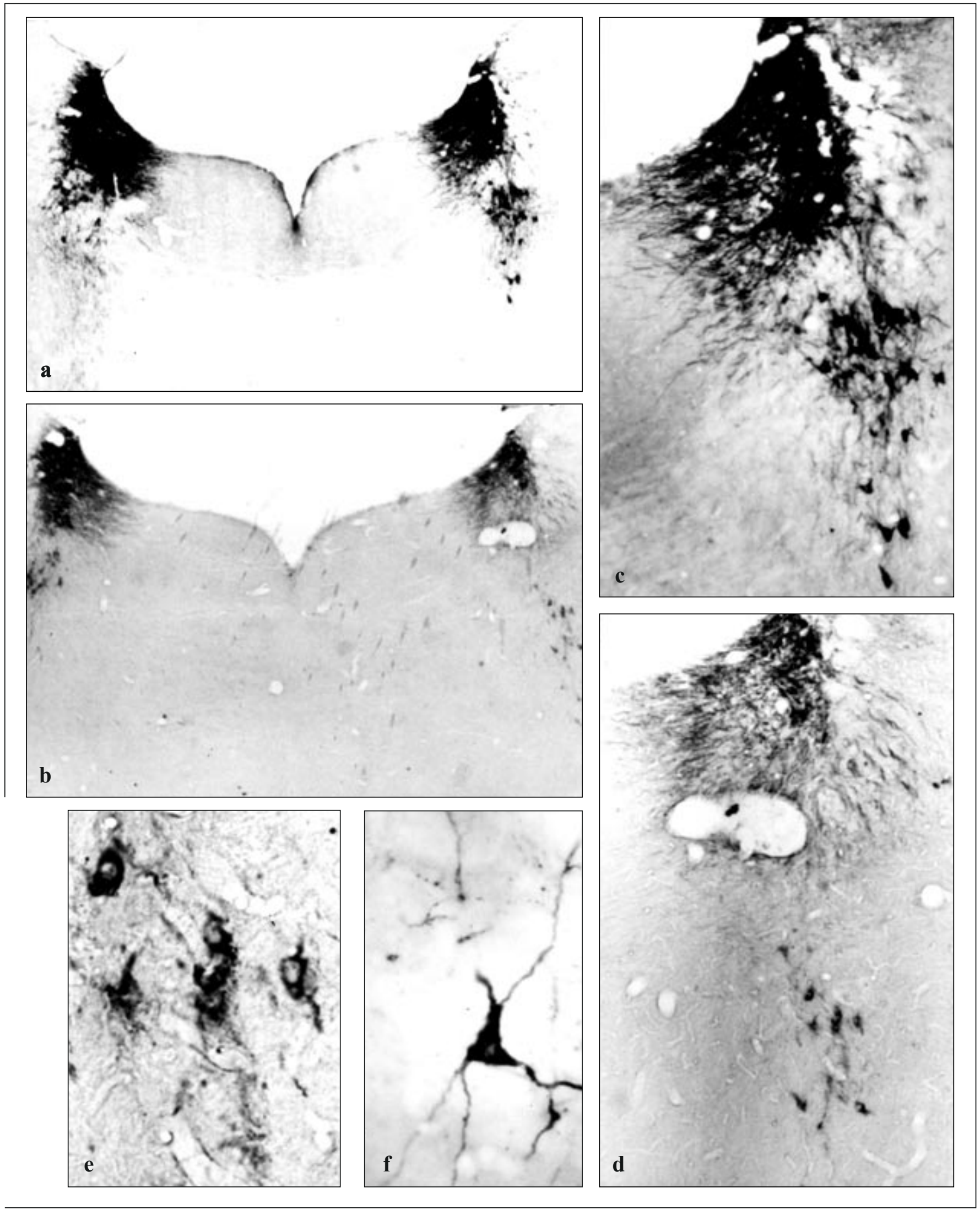




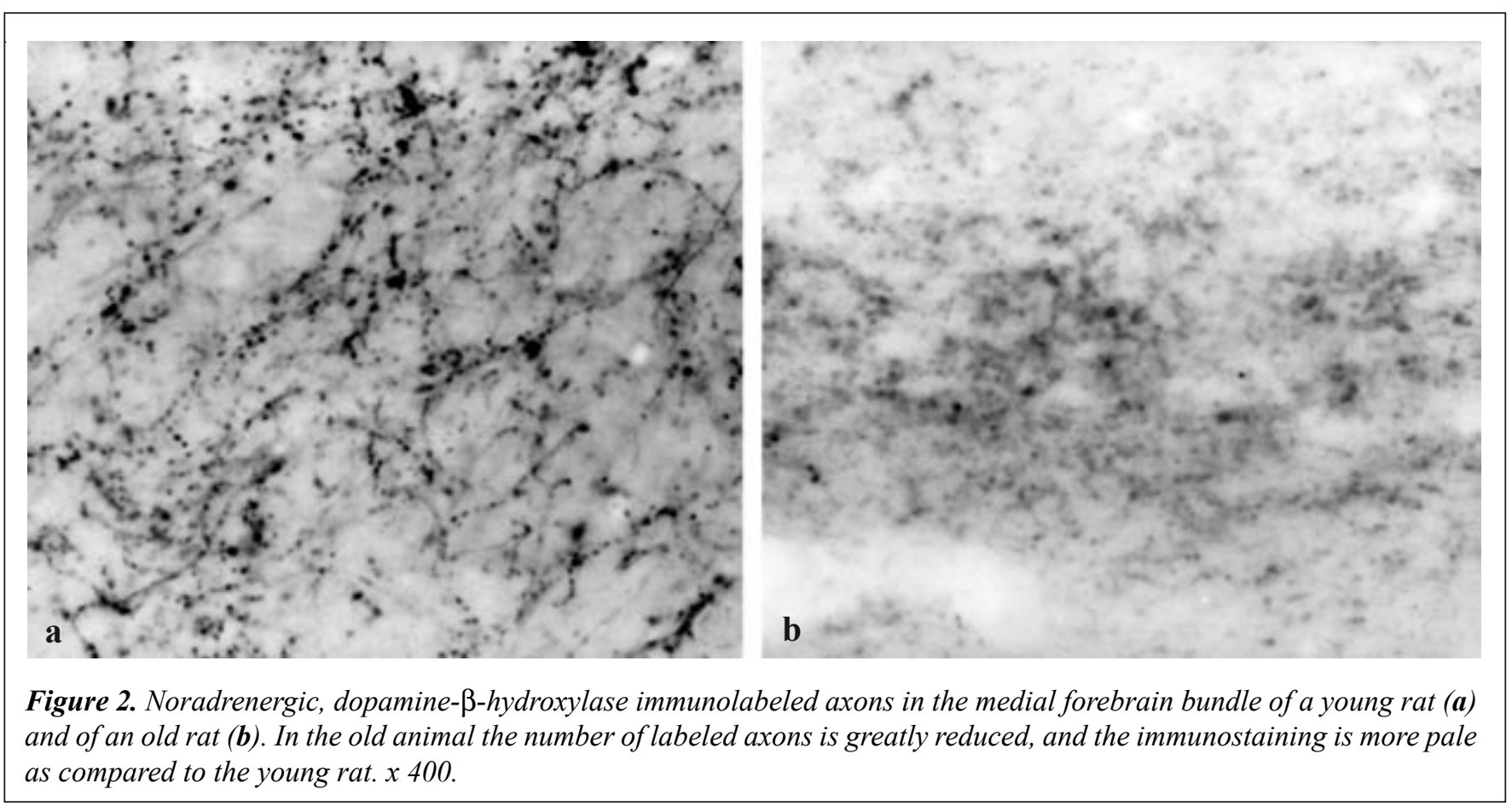

\section{CONCLUSION}

$\mathrm{NM}$ is a pigment that accumulates in the majority primate central nervous system CAergic neurons. The NM-containing neurons are involved in severe diseases, including Parkinson's disease and Alzheimer's disease. Therefore, the data on the normal aging of NM-containing neurons are especially important. Although a subject of intensive research, the precise involvement of NM in the development of Parkinson's disease is still controversial. A better understanding of this issue could provide new strategies in the treatment of human neurological disease.

\section{REFERENCES}

1. Usunoff KG, Itzev DE, Ovtscharoff WA, Marani E. Neuromelanin in the human brain: a review and atlas of pigmented cells in the substantia nigra. Arch Physiol Biochem 2002; 110: 257-369.

2. Hirsch EC, Graybiel AM, Agid YA. Melanized dopaminergic neurons are differentially susceptible to degeneration in Parkinson's disease. Nature 1988; 334: 345-348.

3. Hirsch EC. Why are nigral catecholaminergic neurons more vulnerable than other cells in Parkinson's disease? Ann Neurol 1992; 32: S88-S93.

4. Bogerts B. A brainstem atlas of catecholaminergic neurons in man, using melanin as a natural marker. J Comp Neurol 1981; 197: 63-80.

5. SaperCB, Petito C. Correspondence of melanin-pigmented neurons in human brain with A1-A14 catecholamine cell groups. Brain Res 1982; 105: 87-101.

6. Dahlstrom A, Fuxe K. Evidence for the existence of monoamine neurons in the central nervous system. I. Demonstration of monoamines in the cell bodies of brainstem neurons. Acta Physiol Scand 1964; 62: Suppl. 232: 1-55.

7. Hassler R. Zur Pathologie der Paralysis agitans und des postencephalitischen Parkinsonismus. J Psychol Neurol 1938; 48: 387-476.

8. Hassler R. Zur pathologischen Anatomie des senilen und des parkinsonistischen Tremor. J Psychol Neurol 1939; 49: 193-230.

9. Greenfield JG, Bosanquet FD. The brain stem lesions in parkinsonism. J Neurol Neurosurg Psychiatry 1953; 16: 213-226.

10. Forno LS. Neuropathology of Parkinson's disease. $J$ Neuropathol Exp Neurol 1996; 55: 259-272.

11. Jellinger $\mathrm{K}$. The neuropathologic diagnosis of secondary parkinsonian syndromes. In: Battistin L, Scarlato G, Caraceni T, Ruggieri S, editors. Parkinson's Disease, Advances in Neurology Vol. 69. Lippincott-Raven, Philadelphia, 1996; 293-303.

12. Lowe J, Lennox G, Leigh PN. Disorders of movement and system degenerations. In: Graham DI, Lantos PL, editors. Greenfield's Neuropathology Vol. 2, $6^{\text {th }}$ Edition. Arnold, London, 1997; 281-366.

13. Mann DMA, Yates PO, Hawkes J. The noradrenergic system in Alzheimer's and multi-infarct dementias. $J$ Neurol Neurosurg Psychiatry 1982; 45: 113-119. 
14. Mann DM, Yates PO, Hawkes J. The pathology of the human locus coeruleus. Clin Neuropathol 1983; 2: 1-7.

15. Mann DMA, Yates PO, Marcyniuk B. Dopaminergic neurotransmitter system in Alzheimer's disease and in Down's syndrome at middle age. J Neurol Neurosurg Psychiatry 1987; 50: 341-344.

16. Bondareff W, Mountjoy CQ, Roth M, Hauser DL. Neurofibrillary degeneration and neuronal loss in Alzheimer's disease. Neurobiol Aging 1989; 10: 709715 .

17. Esiri MM, Hyman BT, Beyreuther K, Masters CL. Ageing and dementia. In: Graham DI, Lantos PL, editors. Greenfield's Neuropathology Vol. 2, 6th Edition. Arnold, London, 1997; 153-234.

18. Marsden CD. Neuromelanin and Parkinson's disease. In: Birkmayer W, Duvoisin RC, editors. Extrapyramidal Disorders, J Neural Transm 1983; Suppl. 19: 121-142.

19. Lindquist NG, Larsson BS, Lyden-Sokolowski A. Neuromelanin and its possible protective and destructive properties. Pigment Cell Res 1987; 1: 133-136.

20. Kastner A, Hirsch EC, Lejeune O, Javoy-Agid F, Rascol $\mathrm{O}$, Agid Y. Is the vulnerability of neurons in the substantia nigra of patients with Parkinson's disease related to their neuromelanin content? J Neurochem 1992; 59: 10801089.

21. Youdim MBH, Ben-Schahar D, Riederer P. The enigma of neuromelanin in Parkinson's disease substantia nigra. J Neural Transm 1994; Suppl. 43: 113-122.

22. Jellinger KA. Movement disorders with tau protein cytoskeletal pathology. In: Stern GM, editor. Parkinson's Disease, Advances in Neurology Vol. 80. Lippincott, Williams and Wilkins, Philadelphia, 1999; 303-311.

23. Friede R. Uber die mutmassliche Bedeutung des Melanins in der Substantia nigra. Arch Exp Pathol Pharmak 1953; 118: 285-289.

24. Stilling B. Disquisitione de structura et functionibus cerebri I. De structura protuberantie annularis sive pontis Varoli, Jenae, 1846.

25. Pilcz A. Beitrag zur Lehre von den Pigmentbildung in den Nervenzellen. Arb Inst Anat Physiol Univ Wien 1895; 3: 123-139.

26. Calligaris G. Beitrag zum Studium der Zellen des Locus coeruleus und der Substantia nigra. Monatschr Psychiat Neurol 1908; 24: 339-353.

27. Cooper ERA. The development of the substantia nigra. Brain 1946; 69: 22-33.

28. Mettler F. Neuroanatomy. C. V. Cosby Company, St. Louis, 1948.

29. Olszewski J, Baxter D. Cytoarchitecture of the Human Brain Stem. S. Karger, Basel, 1954.

30. Foley JM, Baxter D. Observations on the cells of the locus coeruleus and substantia nigra. J Neuropathol Exp Neurol 1956; 15: 219-220.

31. Foley JM, Baxter D. On the nature of pigment granules in the cells of the locus coeruleus and substantia nigra. $J$ Neuropathol Exp Neurol 1958; 17: 586-598.

32. Nieto D, Nieto A, Briones MJ. Filogenia y ontogenia de la sustantia negra. Neurol Neurocir Psiquiatr 1967; 8: 33-55.

33. Fenichel GM, Bazelon M. Studies on neuromelanin. II. Melanin in the brain stem of infants and children. Neurology 1968; 18: 817-820.

34. Mann DM, Yates PO, Barton CM. Variations in melanin content with age in the human substantia nigra. Biochem Exp Biol 1977a; 13: 137-139.

35. Barden H. The biology and chemistry of neuromelanin. In: Sohal RS, editor. Age Pigments. Elsevier/North-Holland Biomedical Press, Amsterdam, 1981; 155-180.

36. Lillie RD. The basophilia of melanins. $J$ Histochem Cytochem 1955; 3: 453-454.

37. Cowen D. The melanoneurons of the human cerebellum (nucleus pigmetosus cerebellaris) and homologues in the monkey. J Neuropathol Exp Neurol 1986; 45: 205-221.

38. Barka T, Anderson PJ. Histochemistry. Theory, Practice and Bibliography. New York, Harper and Row. 1963.

39. Adler A. Melanin pigment in the central nervous system of vertebrate. J Comp Neurol 1939; 70: 315-325.

40. Barden H. Relationship of Golgi thiaminepyrophosphatase and lysosomal acid phosphatase to neuromelanin and lipofuscin in cerebral neurons of the aging rhesus monkey. J Neuropathol Exp Neurol 1970; 29: 225-240.

41. Barden $H$. The histochemical relationships and the nature of neuromelanin. In: Brody H, Harman D, Ordy JM, editors. Aging Vol. 1, Clinical, Morphologic and Neurochemical Aspects in the Aging Central Nervous System. Raven Press, New York, 1975; 79-117.

42. Moses HL, Ganote CE, Beaver DL, Schuffman SS. Light and electron microscopic studies of pigment in human and rhesus monkey substantia nigra and locus coeruleus. Anat Rec 1966; 155: 167-183.

43. Mann DM, Yates PO. Lipofuscin pigments - their relationship to ageing in the human nervous system. I. The lipofuscin content of nerve cells. Brain 1974; 97 : 481-488.

44. Mann DM, Yates PO. Lipoprotein pigments - their relationship to ageing in the human nervous system. II. The melanin content of pigmented nerve cells. Brain 1974; 97: 489-498.

45. Graham DG. On the origin and significance of neuromelanin. Arch Pathol Lab Med 1979; 103: 359-362.

46. Manaye KF, McIntire DD, Mann DMA, German DC. Locus coeruleus cell loss in the aging human brain: A non-random process. J Comp Neurol 1995; 358: 79-87.

47. Bazelon M, Fenichel GM, Randall J. Studies on neuromelanin. I. A melanin system in the human adult brainstem. Neurology 1967; 17: 512-519.

48. Mann DM, Yates PO. The effects of ageing on the pigmented nerve cells of the human locus coeruleus and 
substantia nigra. Acta Neuropathol (Berl) 1979; 47: 9397.

49. Mann DM, Yates PO, Barton CM. Neuromelanin and RNA in cells of substantia nigra. J. Neuropathol Exp Neurol 1977; 36: 379-383.

50. Gellerstedt N. Zur Kentnis der Hirnveraenderungen bei der normalen Altersivolution. Uppsala Lak-Foren Forh 1933; 38: 193-408.

51. Mann DMA, Yates PO, Marcyniuk B. Monoaminergic neurotransmitter systems in presenile Alzheimer's disease and in senile dementia of Alzheimer type. Clin Neuropathol 1984; 3: 199-205.

52. Fearnley J, Lees A. Ageing and Parkinson's disease: substantia nigra regional selectivity. Brain 1991; 114: 2283-2301.

53. Gibb WRG. Neuropathology of the substantia nigra. Eur Neurol 1991; 31: Suppl. 1: 48-59.

54. McGeer PL, McGeer EG, Suzuki JS. Aging and extrapyramidal function. Arch Neurol 1977; 34: 33-35.

55. Fearnley J, Lees A. Pathology of Parkinson's disease. In: Calne DB, editor. Neurodegenerative diseases. Philadelphia, WB Saundrs, 1994; 545-554.

56. Tooyama I, McGeer EG, Kawamata T, Kimura H, McGeer PL. Retention of basic fibroblast growth factor immunoreactivity in dopaminergic neurons of the substantia nigra during normal aging in humans contrasts with loss in Parkinson's disease. Brain Res 1994; 656: 165-168.

57. Bannon MJ, Whitty CJ. Age-related and regional differences in dopamine transporter mRNA expression in human midbrain. Neurology 1997; 48: 969-977.

58. Faraldi F, Reyes, MG, Alfieri E, Levi AC. The aging substantia nigra: quantitative histologic study. Panminerva Med 1994; 36: 103-108.

59. Graham DG. Oxidative pathways for catecholamines in the genesis of neuromelanin and cytotoxic quinones. Molec Pharmacol 1978; 14: 633-643.

60. Riederer P, Wuketich S. Time course of nigrostriatal degeneration in Parkinson's disease. A detailed study of influential factors in human brain amine analysis. J Neural Transm 1976; 38: 277-301.

61. Carlsson A, Nyberg P, Winbald B. The influence of age and other factors on concentrations of monoamines in the human brain. In: Nyberg P, editor. Brain Monoamines in Normal Aging and Dementia. Umea Medical Dissertations, Sweden. 1984.

62. Scherman D, Desnos C, Darchen F, Pollak P, Javoy-Agid F, Agid Y. Striatal dopamine deficiency in Parkinson's disease: role of aging. Ann Neurol 1989; 26: 551-557.

63. Marsden CD. Parkinson's disease. Lancet 1990; 335: 948-952.

64. Vijayshankar N, Brody H. A quantitative study of the pigmented neurons in the nuclei locus coeruleus and subcoeruleus in man as related to aging. $J$ Neuropathol
Exp Neurol 1979; 38: 490-496.

65. Wree A, Braak H, Schleicher A, Zilles K. Biomathematical analysis of the neuronal loss in the aging human brain of both sexes, demonstrated in pigment preparations of the pars cerebellaris loci coerulei. Anat Embryol (Berl) 1980; 160: 105-119.

66. Tomlinson BE, Irving D, Blessed G. Cell loss in the locus coeruleus in senile dementia of Alzheimer type. J Neurol Sci 1981; 49: 419-428.

67. Bondareff W, Mountjoy CQ, Roth M. Loss of neurons of origin of the adrenergic projection to cerebral cortex (nucleus locus coeruleus) in senile dementia. Neurology 1982; 32: 164-168.

68. Iversen IL, Rossor MN, Reynolds GP, Hills R, Roth M, Mountjoy CQ, et al. Loss of pigmented dopamine-betahydroxylase positive cells from locus coeruleus in senile dementia of Alzheimer's type. Neurosci Lett 1983; 39: 95-100.

69. Tomonaga M. Neuropathology of the locus ceruleus: a semi-quantitative study. J Neurol 1983; 230: 231-240.

70. Yoshinaga T. Morphometric study of the human locus coeruleus: the changes with ageing and degenerative diseases. Fukuoka Igaku Zasshi 1986; 77: 293-308.

71. German DC, Walker BS, Manaye K, Smith WR, Woodward DJ, North AJ. The human locus coeruleus: computer reconstruction of cellular distribution. $J$ Neurosci 1988; 8: 1776-1788.

72. Lohr JB, Jeste DV. Locus coeruleus morphometry in aging and schizophrenia. Acta Psychiatr Scand 1988; 77: 689-697.

73. Chan-Palay V, Asan E. Alterations in the catecholamine neurons of the locus coeruleus in senile dementia of the Alzheimer type and in Parkinson's disease with and without dementia and depression. J Comp Neurol 1989; 287: 373-392.

74. Ohm TG, Busch C, Bohl J. Unbiased estimation of neuronal numbers in the human nucleus coeruleus during aging. Neurobiol Aging 1997; 18: 393-399.

75. Baker KG, Tork I, Hornung JP, Halasz P. The human locus coeruleus complex: an immunohistochemical and three dimensional reconstruction study. Exp Brain Res 1989; 77: 257-270.

76. Marcyniuk B, Mann DMA, Yates PO. The topography of nerve cell loss from the locus coeruleus in elderly persons. Neurobiol Aging 1989; 10: 5-9.

77. Gundersen HJG, Jensen EB. The efficiency of systematic sampling in stereology and its prediction. JMicrosc 1987; 147: 3-45.

78. Gundersen HJG, Bagger P, Bendtsen TF, Evans M, Korbo L, Marcussen N, et al. The new stereological tools: disector, fractionator, nucleator and point sampled intercepts and their use in pathological research and diagnosis. APMIS 1988; 96: 857-881.

79. VanDongen PAM. The human locus coeruleus in neurology 
and psychiatry (Parkinson's, Lewy body, HallervordenSpatz, Alzheimer's and Korsakoff's disease, (pre)senile dementia, schizophrenia, affective disorders, psychosis). Prog Neurobiol 1981; 17: 97-139.

80. Mouton PR, Pakkenberg B, Gundersen HJ, Price DL. Absolute number and size of pigmented locus coeruleus neurons in young and aged individuals. J Chem Neuroanat 1994; 7: 185-190.

81. Chan-Palay V, Asan E. Quantitation of catecholamine neurons in the locus coeruleus in human brains of normal young and old adults and in depression. J Comp Neurol 1989; 287: 357-372.

82. Kubis N, Faucheux BA, Ransmavr G, Damier P, Duyckaerts C, Henin D, et al. Preservation of midbrain catecholaminergic neurons in very old human subjects. Brain 2000; 123: 366-373.

83. Scherer HJ. Melanin pigmentation of the substantia nigra in primates. J Comp Neurol 1939; 71: 91-95.

84. Adler A. Melanin pigment in the brain of the gorilla. $J$ Comp Neurol 1942; 76: 501-507.

85. Brown JO. Pigmentation of substantia nigra and locus coeruleus in certain carnivores. J Comp Neurol 1943; 79: 393-405.

86. Gutner II. On the deposition of melanin in the nerve cells of the dog. Dokl Acad Nauk SSSR Otd Biokh 1954; 97: 531-533

87. Barden H, Barrett R. The localization of catecholamine fluorescence to dog hypothalamic neuromelanin-bearing neurons. J Histochem Cytochem 1973; 21: 175-183.

88. DeMattei M, Levi AC, Fariello RG. Neuromelanic pigment in substantia nigra neurons of rats and dogs. Neurosci Lett 1986; 72: 37-42.

89. Marsden CD. The development of pigmentation and enzyme activity in the nucleus substantiae nigrae of the cat. J Anat (London) 1965; 99: 175-180.

90. Usunoff KG. Cytoarchitectural, Ultrastructural and Histochemical Characterization of Substantia Nigra. DSc Thesis, Vols. I - VI, Medical Academy, Sofia, 1990.

91. Pakkenberg H, Andersen BB, Burns RS, Pakkenberg B. A stereological study of substantia nigra in young and old rhesus monkeys. Brain Res 1995; 693: 201-206.

92. Cozzi B, Pellegrini M, Droghi A. Neuromelanin in the substantia nigra of adult horses. Anat Anz 1988; 166: 53 61 .

93. Herrero MT, Hirsch EC, Kastner A, Ruberg M, Luquin MR, Laguna J, et al. Does neuromelanin contribute to the vulnerability of catecholaminergic neurons in monkeys intoxicated with MPTP? Neuroscience 1993; 56: 499511.

94. Irwin I, DeLaney LE, McNeil T, Chan P, Forno LS, Murphy GM, et al. Aging and the nigrostriatal dopamine system: a non-human primate study. Neurodegeneration 1994; 3: 251-265.

95. Siddiqi ZA, Peters A. The effect of aging on pars compacta of the substantia nigra in rhesus monkey. J Neuropathol Exp Neurol 1999; 58: 903-920.

96. Marsden CD. Pigmentation of nucleus substantiae nigrae of mammals. J Anat (London) 1961; 95: 256-261.

97. Poirier LJ, Giguere M, Marchand R. Comparative morphology of the substantia nigra and ventral tegmental area in the monkey, cat and rat. Brain Res Bull 1983; 11: 371-398.

98. Sturrock RR, Rao KA. A quantitative histological study of neuronal loss from the locus coeruleus of ageing mice. Neuropathol Appl Neurobiol 1985; 11: 55-60.

99. Shores MM, White SS, Veith RC, Szot P. Tyrosine hydroxylase mRNA is increased in old age and norepinephrine uptake transporter mRNA is decreased in middle age in locus coeruleus of Brown-Norway rats. Brain Res 1999; 826: 143-147.

100. Tatton WG, Greenwood CE, Salo PT, Seniuk NA. Transmitter synthesis increases in substantia nigra neurons of the aged mouse. Neurosci Lett 1991; 131: 179-182.

101. Greenwood CE, Tatton WG, Seniuk NA, Biddle FG. Increased dopamine synthesis in aging substantia nigra neurons. Neurobiol Aging 1991; 12: 557-565.

102. McNeill TH, Koek LL, Haycock JW. The nigrostriatal system and aging. Peptides 1984; 5 Suppl. 1: 263-268.

103. McNeill TH, Koek LL, Haycock JW. Age-correlated changes in dopaminergic nigrostriatal perikarya of the C57BL/6NNia mouse. Mech Ageing Dev 1984; 24: 293307.

104. McNeill TH, Koek LL. Differential effects of advancing age on neurotransmitter cell loss in the substantia nigra and striatum of C57BL/6N mice. Brain Res 1990; 521: 107-117.

105. Voogt JL, Arbogast LA, Quadri SK, Andrews G. Tyrosine hydroxylase messenger RNA in the hypothalamus, substantia nigra and adrenal medulla of old female rats. Mol Brain Res 1990; 8: 55-62.

106. Emerich DF, McDermott P, Krueger P, Banks M, Zhao $\mathrm{J}$, Marszalkowski J, et al. Locomotion of aged rats: relationship to neurochemical but not morphological changes in nigrostriatal dopaminergic neurons. Brain Res Bull 1993; 32: 477-486.

107. Schuligoi R, Fernandez J, Heavens RP, Sirinathsinahii DJ. Decreased tyrosine hydroxylase mRNA but not cholecystokinin mRNA in the pars compacta of the substantia nigra and ventral tegmental area of aged rats. Mol Brain Res 1993; 19: 333-338.

108. Himi T, Cao MH, Mori N. Reduced expression of the molecular markers of dopaminergic neuronal atrophy in the aging rat brain. J Gerontol 1995; 50: 193-200.

109. DeLaCruz CP, Revilla E, Venero GL, Ayala A, Cano J, Machado A. Oxidative inactivation of tyrosine hydroxylase in substantia nigra of aged rat. Free Radic Biol Med 1996; 20: 53-61. 